\title{
GAMBARAN TINGKAT PENGETAHUAN TENTANG KANKER PAYUDARA DAN PERILAKU PERIKSA PAYUDARA SENDIRI (SADARI)
}

\author{
Elda Dwi Ospah Sihite ${ }^{1}$, Sofiana Nurchayati ${ }^{2}$, Yesi Hasneli ${ }^{3}$ \\ ${ }^{1,2,3}$ Fakultas Keperawatan Universitas Riau \\ Fakultas Keperawatan Universitas Riau Jalan Pattimura No 9 \\ Gedung G Pekanbaru Riau Kode Pos 28131 Indonesia \\ email eldadwi1707@gmail.com
}

\begin{abstract}
Abstrak
Penelitian ini bertujuan untuk mengetahui gambaran tingkat pengetahuan tentang kanker payudara dan perilaku dalam pemeriksaan payudara sendiri (SADARI) di wilayah Puskesmas Rejosari Pekanbaru. Penelitian ini menggunakan deskritif kuantitatif dengan pendekatan cross sectional. Pengambilan sampel mengunakan teknik purposive sampling. Jumlah sampel dalam penelitian ini 100 responden. Alat pengumpul data yang digunakan kuesioner dan lembar observasi check list. Kuesioner digunakan untuk mengukur tingkat pengetahuan kanker payudara dan SADARI yang telah diuji validitas dan reliabilitas. Lembar observasi check list untuk mengukur perilaku SADARI. Analisa yang digunakan analisa univariat. Hasil penelitian menunjukkan bahwa sebagian besar responden berumur 36-45 tahun (dewasa akhir) sebanyak 59 responden (59\%), pendidikan SMA sebanyak 45 responden (45\%), pekerjaan Ibu rumah tangga sebanyak 82 responden (82\%), status perkawinan menikah 94 responden (94\%), tingkat pengetahuan cukup sebanyak 37 responden (37\%), dan perilaku SADARI tidak melakukan sebanyak 71 responden (71\%). Disarankan kepada petugas kesehatan untuk meningkatkan edukasi kepada Wanita Usia Subur (WUS) dan masyarakat agar mendeteksi secara dini guna mencegah terjadinya kanker payudara.
\end{abstract}

Kata kunci: Kanker payudara, Pengetahuan, Perilaku, SADARI

\begin{abstract}
The purpose of this research was to detemine descripction level of knowlegde about breast cancer and breast self-examination (BSE) behavior in Puskesmas Rejosari Pekanbaru area. This research uses descriptive quantitative using cross sectional. Sampling using purposive sampling technique. The number of samples in this research were 100 respondents. Data collection tool used questionnaire and checklist observation sheet. The questionnaire was used to measure the level of knowledge of breast cancer and BSE has tested the validity and reliability. Observation sheet checklist to measure BSE behavior. The analysis used univariate analysis. The results showed that the majority of respondents for 36-45 years (late adulthood) were 59 respondents (59\%), level of education was senior high school as 45 respondents (45\%), housewife work as many as 82 respondents (82\%), marital status was married 94 respondents (94\%), sufficient level of knowledge as many as 37 respondents (37\%), and BSE behavior did not do as many as 71 respondents (71\%). It is recommended to health workers to improve education for women age fertile (WAF) and society to detect early to prevent breast cancer.
\end{abstract}

Keywords: Behavior, Breast cancer, Breast self-examination (BSE), Knowledge 
Elda Dwi Ospah Sihite, Sofiana Nurchayati, dan Yesi Hasneli, Gambaran Tingkat Pengetahuan tentang Kanker Payudara dan Perilaku Periksa Payudara Sendiri (SADARI)

\section{PENDAHULUAN}

Kanker payudara adalah keganasan sel-sel pada jaringan payudara, bisa berasal dari komponen kelenjarnya (epitel saluran maupun lobulusnya) seperti jaringan lemak, pembuluh darah, dan persyarafan jaringan payudara (Rasjidi, 2010). Kanker payudara dapat mengakibatkan kematian pada wanita lebih dari 508.000 tahun 2011 di seluruh dunia dan dianggap sebagai penyakit di negara maju hampir 50\% kasus kanker payudara dan 58\% kematian terjadi di negara-negara kurang berkembang (WHO, 2018).

Kanker payudara pada tahun 2018 di Asia sebesar 674.693 kasus $(25,5 \%)$. Kematian akibat kanker payudara sebesar 310.577 kasus $(13,8 \%)$ (IARC, 2018). Kanker payudara di Indonesia didapatkan kurang lebih 23.140 kasus baru setiap tahun (200 juta populasi) (Suyatno \& Emir, 2014). Kanker payudara di provinsi Riau cukup tinggi yaitu $0,3 \%$ atau 190.332 jiwa dari 63.444 .000 penduduk (Kemenkes RI, 2015).

Wanita yang memiliki risiko tinggi terkena kanker payudara adalah wanita usia subur (Rasjidi, 2010). Wanita usia subur adalah wanita dalam usia reproduktif 15-49 tahun (Kemenkes RI, 2015). Data dari Dinas Kesehatan Kota Pekanbaru (2018), wanita usia subur di Puskesmas Rejosari usia 15-39 tahun sebanyak 23.468 orang, 15-49 tahun sebanyak 30.032 orang dan wanita usia subur 30-50 tahun sebanyak 15.347 orang.

Penyebab kanker payudara secara pasti belum diketahui, kanker payudara meningkat pada wanita yang mempunyai faktor-faktor risiko (Suyatno \& Emir, 2014). Kanker payudara terdiagnosa stadium lanjut, karena upaya deteksi dini kanker payudara yang masih kurang (Kemenkes RI, 2015). Akibat tingginya tingkat insiden kanker payudara salah satunya adalah masih rendah pengetahuan dan pemahaman masyarakat atau pemahaman masyarakat akan bahaya kanker payudara dan kesadaran penting melakukan pemeriksaan dini (Thaha \& Widajadnja, 2017).

Thaha (2017) dalam penelitian menunjukkan bahwa responden memiliki tingkat pengetahuan tinggi sebanyak 53 orang 
$(53,0 \%)$ dan tingkat pengetahuan rendah sebanyak 47 orang $(47 \%)$. Hal ini sejalan dengan penelitian Sari (2016) bahwa pengetahuan kanker payudara wanita usia subur usia 27-28 tahun memiliki pengetahuan tinggi sebanyak 22 orang $(72,2 \%)$, memiliki pengetahuan cukup sebanyak 6 orang $(16,6 \%)$ dan memiliki pengetahuan kurang sebanyak 4 orang $(11,2 \%)$.

Mayoritas responden sudah mengerti kanker payudara secara umum, yaitu pengertian kanker payudara, penyebab terjadinya kanker payudara namun responden belum mengetahui secara tepat apa saja faktor resiko terjadinya kanker payudara, tanda dan gejala serta bagaimana pencegahan kanker payudara (Thaha,2017).

Wanita perlu tahu tentang pengetahuan tentang kanker payudara dan pemeriksaan payudara sendiri (Rasjidi, 2010). Saryono (2009) menyatakan kanker payudara dapat dideteksi dini dengan melakukan pemeriksaan payudara sendiri (SADARI).

Hanson (2017) dalam penelitiannya menunjukkan bahwa responden tidak mampu melakukan SADARI sebanyak 228 orang
$(66,1 \%)$ dan responden yang mampu melakukan SADARI sebanyak 117 orang $(33,9 \%)$. Hal ini dikarenakan masih rendahnya tingkat pengetahuan dan perilaku periksa payudara sendiri (SADARI).

Pengetahuan merupakan domain yang membentuk tindakan seseorang (overt behavior) dari pengalaman dan penelitian, ternyata perilaku didasari oleh pengetahuan akan lebih langgeng daripada perilaku yang tidak didasari oleh pengetahuan (Notoatmodjo, 2012).

Notoatmodjo (2012) menjelaskan perilaku seseorang atau masyarakat tentang kesehatan ditentukan oleh pengetahuan, sikap, kepercayaan, dan tradisi. Masih kurangnya kesadaran wanita-wanita Indonesia dalam melakukan deteksi dini terhadap kanker payudara, masih banyak wanita Indonesia belum mengetahui cara-cara deteksi dini kanker payudara meyebabkan angka kejadian kanker payudara cukup besar.

Studi pendahuluan dilakukan oleh peneliti melalui wawancara kepada 5 orang wanita usia subur yang aktif dalam kegiatan kemasyarakatan di wilayah kerja Puskesmas 
Elda Dwi Ospah Sihite, Sofiana Nurchayati, dan Yesi Hasneli, Gambaran Tingkat Pengetahuan tentang Kanker Payudara dan Perilaku Periksa Payudara Sendiri (SADARI)

Rejosari Pekanbaru pada 15 Maret 2019, yang diambil 100 sampel dengan teknik

ternyata 5 dari 5 wanita mengetahui kanker payudara, 3 dari 5 wanita tidak mengetahui penyebab kanker payudara, 3 dari 5 wanita tidak mengetahui tanda dan gejala kanker payudara, 4 dari 5 wanita tidak mengetahui tingkatan stadium, 4 dari 5 wanita tidak mengetahui SADARI, 5 dari 5 wanita tidak mengetahui waktu pemeriksaan SADARI, 4 dari 5 wanita tidak mengetahui manfaat SADARI, dan 5 dari 5 wanita tidak mengetahui langkah SADARI.

Berdasarkan uraian fenomena diatas peneliti tertarik untuk melakukan penelitian terkait "Gambaran tingkat pengetahun tentang kanker payudara dan perilaku periksa payudara sendiri (SADARI) di wilayah kerja Puskesmas Rejosari Pekanbaru”

\section{METODE PENELITIAN}

Penelitian ini menggunakan penelitian deskriptif kuantitatif dengan pendekatan cross sectional. Populasi penelitian ini adalah seluruh wanita usia subur usia 15-49 tahun di wilayah kerja Puskesmas Rejosari. Sampel

purporsive sampling.

Alat pengumpul data penelitian ini digunakan kuesioner dan lembar observasi check list. Kuesioner digunakan untuk mengukur tingkat pengetahuan kanker payudara dan periksa payudara sendiri (SADARI). Jumlah pertanyaan terdiri dari 15 pertanyaan dengan mutiple choiche. Lembar observasi digunakan untuk menilai perilaku SADARI. Sebelum kuesioner dibagikan kepada responden, kuesioner dilakukan uji validitas dan uji reliabilitas.

Uji validitas menggunakan $r$ tabel dan uji reliabilitas menggunakan $\alpha$ Cronbach's. Pengolahan data penelitian dilakukan dengan cara editing, coding, entry dan tabulating dengan menggunakan program komputer. Analisa data yang digunakan analisa univariat yaitu distribusi frekuensi. 


\section{HASIL PENELITIAN}

\section{Karakteristik responden}

Tabel 1

Distribusi Frekuensi Karakteristik Umur,

Pendidikan, Pekerjaan, Status Perkawinan

Karakteristik

Frekuensi Persentase

(f)

$(\%)$

Umur:

- Dewasa awal (26-35

20

20 tahun)

- Dewasa akhir (36-45 59 tahun)

- Lansia awal (46-55

21 tahun)

\begin{tabular}{lcc}
\hline Total & 100 & 100 \\
\hline Pendidikan: & & \\
- SD & 15 & 15 \\
- SMP/MTS & 15 & 15 \\
- SMA/SMK & 45 & 45 \\
- PT & 20 & 20 \\
- Lain-lainnya & 5 & 5 \\
\hline Total & 100 & 100 \\
\hline
\end{tabular}

Pekerjaan:

- PNS

- Swasta 14 14

- Buruh 3

3

- IRT/lain-lain

\begin{tabular}{lll}
\hline Total & 100 & 100 \\
\hline
\end{tabular}

Status perkawinan

\begin{tabular}{lcc} 
- Menikah & 94 & 94 \\
- Janda & 6 & 6 \\
\hline Total & 100 & 100 \\
\hline
\end{tabular}

Berdasarkan tabel 1 karakteristik responden diketahui sebagian besar responden umur 36-45 tahun (dewasa akhir) yaitu sebanyak 59 responden $(59 \%)$, sedangkan sebagian besar pendidikan terakhir yaitu SMA/SMK sebanyak 45 responden (45\%), sebagian besar pekerjaan responden adalah ibu rumah tangga sebanyak 82 responden (82\%), dan sebagian besar status perkawinan yaitu menikah sebanyak 94 responden (94\%).

\section{Tingkat pengetahuan tentang kanker payudara dan periksa payudara sendiri (SADARI)}

Tabel 2

Distribusi frekuensi berdasarkan tingkat pengetahuan tentang kanker payudara dan periksa payudara sendiri (SADARI)

\begin{tabular}{lcc}
\hline Pengetahuan & Frekuensi & Persentase \\
\hline - Baik & (f) & $(\%)$ \\
- Cukup & 35 & 35 \\
- Kurang & 37 & 37 \\
\hline Total & 28 & 28 \\
\hline
\end{tabular}

Berdasarkan tabel 2 menunjukkan bahwa sebagian responden memiliki pengetahuan cukup tentang kanker payudara dan periksa payudara sendiri (SADARI) yaitu sebanyak 37 responden $(37 \%)$, sedangkan pengetahuan baik tentang kanker payudara dan periksa payudara sendiri (SADARI) sebanyak 35 responden (35\%), dan sebanyak 28 orang (28\%) memiliki pengetahuan kurang tentang kanker payudara periksa payudara sendiri (SADARI). 
Elda Dwi Ospah Sihite, Sofiana Nurchayati, dan Yesi Hasneli, Gambaran Tingkat Pengetahuan tentang Kanker Payudara dan Perilaku Periksa Payudara Sendiri (SADARI)

\section{Gambaran Perilaku SADARI}

Tabel 3

\section{Distribusi frekuensi perilaku}

\begin{tabular}{lcc}
\multicolumn{1}{c}{ Perilaku } & $\begin{array}{c}\text { Frekuensi } \\
(\mathrm{f})\end{array}$ & $\begin{array}{c}\text { Persentase } \\
(\%)\end{array}$ \\
\hline - $\begin{array}{l}\text { Dilakukan dengan } \\
\text { benar }\end{array}$ & 6 & 6 \\
- $\begin{array}{l}\text { Dilakukan tapi tidak } \\
\text { benar }\end{array}$ & 23 & 23 \\
- Tidak dilakukan & 71 & 71 \\
\hline Total & 100 & 100 \\
\hline
\end{tabular}

Berdasarkan tabel 3 menunjukkan bahwa sebagian besar responden tidak melakukan perilaku periksa payudara sendiri (SADARI) sebanyak 71 responden $(71 \%)$, sedangkan yang melakukan perilaku periksa payudara sendiri (SADARI) dengan benar yaitu sebanyak 6 responden $(6 \%)$, dan perilaku periksa payudara sendiri (SADARI) dilakukan tapi tidak benar sebanyak 23 responden (23\%).

\section{PEMBAHASAN}

A. Pembahasan hasil penelitian

\section{Karakteristik responden}

\section{a. Umur}

Hasil penelitian yang telah dilakukan diperoleh bahwa seebagian besar responden berada pada kelompok dewasa akhir yaitu umur 36-45 tahun sebanyak 59 responden
(59\%). Hasil penelitian ini sesuai dengan penelitian yang dilakukan oleh Desi, Priyantari dan Lubis (2017) bahwa sebagian besar responden berumur 36-45 tahun sebanyak 27 responden $(38,1 \%)$.

Hal ini menunjukkan bahwa wanita berumur 36-45 tahun menunjukkan sifat berpikir yang sudah matang dan memiliki mental untuk mempelajari dan menyesuaikan diri pada situasi-situasi baru, misalnya mengingat hal-hal yang dulu pernah dipelajari, penalaran anologi dan berpikir kreatif.

Notoatmodjo (2012) menyatakan semakin tua umur seseorang, maka semakin berkembang daya tangkap dan pola pikirnya sehingga pengetahuan yang diperoleh semakin baik, tetapi menjelang usia lanjut kemampuan mengingat seseorang akan semakin berkurang.

\section{b. Pendidikan}

Hasil penelitian ini menunjukkan bahwa sebagian besar pendidikan SMA sebanyak 45 responden (45\%). Hasil penelitian ini didukung oleh penelitian Kartika (2015) yang menyatakan sebagian besar responden 
pendidikan SMA sebanyak 34 responden $(36,5 \%)$.

Semakin tinggi pendidikan seseorang semakin mudah pula menerima informasi dan mengolahnya sebelum menjadi perilaku yang baik maupun buruk sehingga berdampak terhadap status kesehatannya (Notoatmodjo, 2012). Jenjang pendidikan sangat berpengaruh terhadap kompetensi yang harus dimiliki seseorang untuk mendapatkan informasi dan pendidikan tinggi seseorang akan cenderung mendapatkan informasi, baik dari orang lain maupun dari media massa.

\section{c. Pekerjaan}

Hasil penelitian didapatkan bahwa sebagian besar pekerjaan ibu rumah tangga sebanyak 82 responden (82\%). Hasil penelitian ini sejalan dengan penelitian yang dilakukan oleh Kartika (2015) bahwa pekerjaan sebagian responden tidak bekerja atau ibu rumah tangga yaitu sebanyak 78 responden $(83,9 \%)$.

Wawan \& Dewi (2010) mengatakan pekerjaan adalah kegiatan dilakukan terutama untuk menunjang kehidupannya dan kehidupan keluarganya. Bekerja umumnya merupakan kegiatan yang menyita waktu.
Bekerja bagi ibu-ibu akan berpengaruh terhadap kehidupan keluarga.

Nurhidayati (2017) dalam penelitiannya mengatakan bahwa ibu yang tidak bekerja cenderung memiliki pengetahuan cukup karena pengalaman. Hal ini sejalan dengan penelitian yang dilakukan Wardani (2017), bahwa ibu tidak bekerja memiliki pengetahuan cukup.

Asumsi peneliti dalam penelitian ini wanita usia subur yang tidak bekerja sebagian besar memiliki pengetahuan cukup. Hal ini mungkin responden yang tidak bekerja memiliki waktu untuk mendapatkan informasi tentang kanker payudara dan SADARI melalui media cetak, media elektronik, tenaga kesehatan yang memberikan penyuluhan.

\section{d. Status perkawinan}

Hasil penelitian didapatkan bahwa sebagian responden menikah sebanyak 94 responden (94\%). Hal ini sejalan dengan penelitian Donnelly (2015) bahwa mayoritas 1063 responden menikah $(78,9 \%)$ dan punya anak $(84,8 \%)$ bahwa wanita yang sudah menikah dengan 1-5 anak, responden lebih mungkin untuk berpartisipasi dalam 
Elda Dwi Ospah Sihite, Sofiana Nurchayati, dan Yesi Hasneli, Gambaran Tingkat Pengetahuan tentang Kanker Payudara dan Perilaku Periksa Payudara Sendiri (SADARI)

melakukan SADARI dari responden yang belum menikah.

Asumsi peneliti wanita usia subur dengan status perkawinan pada penelitian ini bahwa status perkawinan tidak menjamin seseorang memiliki pengetahuan baik mengenai kanker payudara dan SADARI.

Hal ini menunjukkan bahwa status perkawinan tidak mempengaruhi pengetahuan tentang kanker payudara dan SADARI. Status perkawinan tidak menjamin seseorang berpengetahuan baik, tergantung dari minat seseorang pada suatu informasi.

\section{Gambaran tingkat pengetahuan} responden tentang kanker payudara dan periksa payudara sendiri (SADARI)

Hasil penelitian ini menunjukkan bahwa tingkat pengetahuan responden tentang kanker payudara dan periksa payudara sendiri (SADARI) sebagian besar 37 orang responden (37\%) memiliki pengetahuan cukup, sebanyak 35 orang responden $(35 \%)$ memiliki pengetahuan baik dan 28 orang responden (28\%) memiliki pengetahuan kurang.

Hal ini sejalan dengan penelitian Desi,
Priyantari, Lubis (2017) pengetahuan responden memiliki pengetahuan baik sebanyak 28 orang responden $(39,4 \%)$, pengetahuan cukup sebanyak 31 orang responden $(43,7 \%)$, dan pengetahuan kurang sebanyak 12 orang responden $(16,9 \%)$.

Pengetahuan baik bahwa responden mengerti tentang kanker payudara mulai dari pengertian, faktor resiko, tanda gejala, dan pencegahan deteksi dini kanker payudara. Sedangkan tentang SADARI mulai dari pengertian, waktu pelaksanaan, tujuan dan cara melakukan. Hal ini responden sering mendapatkan informasi baik dari media cetak, media informasi, penyuluhan dari petugas kesehatan dan pengalaman.

Pengetahuan cukup bahwa responden mengerti tentang pengertian kanker payudara, tanda gejala, kurang mengerti deteksi dini dan kurang mengerti tentang faktor resiko, hal ini dikarenakan responden cukup dalam memperoleh informasi tentang kanker payudara dan SADARI seperti pengertian SADARI, waktu pelaksanaan, tujuan, dan kurang mengerti tentang cara melakukan 
SADARI secara keseluruhan.

Pengetahuan kurang dikarenakan kurang informasi yang didapatkan oleh responden sehingga tidak berusaha mendapatkan informasi tentang kanker payudara dan SADARI. Keterbatasan informasi menyebabkan pengetahuan responden tentang kanker payudara dan SADARI menjadi kurang.

Pendidikan berpengaruh terhadap pengetahuan dalam memperoleh informasi tentang SADARI. Semakin tinggi pendidikan seseorang semakin banyak menerima informasi. Informasi tentang SADARI memiliki kontribusi dalam hasil penelitian ini seseorang tidak pernah sama sekali mendapatkan informasi tentunya memiliki pengetahuan sedikit bahkan tidak tahu sama sekali tentang SADARI karena belum terpapar informasi tentang SADARI.

Peneliti berasumsi responden dalam penelitian ini memiliki pengetahuan cukup disebabkan salah satunya pendidikan dan lingkungan sehingga responden mengetahui kanker payudara dan cara melakukan deteksi dini terjadinya kanker payudara.
Hal ini sejalan dengan Wawan dan Dewi (2010) bahwa faktor yang mempengaruhi pengetahuan antara lain faktor internal yaitu pendidikan, pekerjaan, umur, dan faktor eksternal antara lain faktor lingkungan dan sosial budaya. Selain itu, kemajuan teknologi dan informasi yang tidak terbatas dan bisa diakses setiap orang sehingga tidak jarang orang lebih muda cenderung lebih pandai dan lebih sering berhubungan dan mengakses teknologi informasi seperti internet sehingga cenderung memiliki tingkat pengetahuan yang lebih tinggi.

\section{Gambaran perilaku periksa payudara sendiri (SADARI)}

Hasil penelitian ini menunjukkan bahwa sebagian besar tidak melakukan perilaku periksa payudara sendiri (SADARI) sebanyak 71 responden $(71 \%)$, perilaku periksa payudara sendiri (SADARI) dilakukan dengan benar sebanyak 6 responden (6\%), dan perilaku periksa payudara sendiri (SADARI) dilakukan tapi tidak benar sebanyak 23 orang responden (23\%). Hasil penelitian ini menunjukkan bahwa responden yang tidak melakukan perilaku SADARI 
Elda Dwi Ospah Sihite, Sofiana Nurchayati, dan Yesi Hasneli, Gambaran Tingkat Pengetahuan tentang Kanker Payudara dan Perilaku Periksa Payudara Sendiri (SADARI)

dengan tepat pada langkah 1,2 , 4, dan 6 . terdapat 35\% yang memiliki pengetahuan baik Yayasan Kanker Payudara Indonesia (2017) mengenai SADARI dan 28\% pengetahuan cara langkah 1 (meletakkan tangan disamping kurang mengenai SADARI. Ibu rumah tangga badan untuk melakukan inspeksi pada yang memiliki pengetahuan baik namun tidak payudara), langkah 4 (gerakan memutar mampu melakukan SADARI dalam hal ini dengan tekanan lembut tetapi mantap, dimulai karena IRT belum mengetahui cara melakukan dari pinggang atas (posisi jam 12) dengan SADARI dengan baik dan benar, mayoritas mengikuti arah jam bergerak ke tengah kearah hanya melakukan salah satu langkah dari puting susu), namun berbeda pada langkah 6 (berbaringlah dengan tangan kiri di bawah kepala, letakkan bantal kecil di bawah bahu kanan, rabalah seluruh permukaan payudara kiri dan kanan dengan gerakan seperti di uraikan), dan responden juga tidak pernah melakukan dengan cara berbaring dan tidak pernah mendengar langkah SADARI dengan cara berbaring.

Hasil penelitian ini sejalan dengan penelitian Nurhidayati (2017), mayoritas ibu tidak dapat melakukan SADARI dengan benar, bahkan 19 ibu sama sekali tidak pernah melakukan SADARI. Hal tersebut dikarenakan beberapa faktor seperti kurangnya pengetahuan ibu tentang SADARI.

Dari segi pengetahuan responden yaitu beberapa langkah dalam melakukan SADARI. Sedangkan perilaku SADARI dilakukan dengan benar oleh responden langkah 1, 2, 3, 4, 5 dan 6. Yayasan Kanker Payudara Indonesia (2017) cara langkah 1 sampai 6 (berdiri di depan cermin dengan mengangkat tangan, melihat bentuk dan ukuran payudara, melihat perubahan warna kulit payudara, memijat hingga puting untuk mengetahui ada tidaknya cairan yang keluar dan meraba seluruh bagian payudara dengan variasi tekanan untuk mengetahui ada tidaknya benjolan serta meraba hingga ketiak). Hal ini sesuai dengan hasil penelitian yang diperoleh bahwa responden mempunyai pengetahuan baik tentang SADARI dan melakukan perilaku langkah-langkah SADARI dengan benar. 
Perilaku periksa payudara sendiri dilakukan tapi tidak benar oleh responden kurang dapat melakukan teknik menekan dan meraba payudara dimulai dari klavikula secara sikuler (memutar), zig-zag, atau gerakan secara mantap dengan 3 jari dari mulai atas hingga bawah dari bagian luar ke dalam pada payudara. Hal ini menunjukan responden belum mengetahui benar cara melakukan SADARI sesuai dengan prosedur yang ada dan pengetahuan responden yang kurang tentang SADARI dapat berdampak pada kemampuan melakukan SADARI responden tidak benar.

$$
\text { Notoatmodjo (2012) mengatakan }
$$
perilaku disebabkan faktor predisposisi yaitu pengetahuan, sikap, kepercayaan, keyakinan dan nilai-nilai. Faktor pendukung yaitu terwujud dalam lingkungan fisik, tersedia atau tidaknya fasilitas atau sarana kesehatan. Faktor pendorong yaitu terwujudnya dalam sikap dan perilaku petugas kesehatan dan petugas lain.

Peneliti berasumsi dalam penelitian ini bahwa perilaku tidak melakukan SADARI disebabkan karena kurang pengetahuan responden tentang SADARI. Hal ini bisa disebabkan oleh faktor lain seperti pengetahuan, pengalaman, keterampilan atau keahlian maupun dorongan dari orang lain.

Adapun 3 alasan responden tidak melakukan SADARI yaitu tidak terdapat masalah payudara, tidak tahu teknik SADARI, dan tidak mengetahui pentingnya SADARI.

\section{SIMPULAN}

Hasil penelitian tentang tingkat pengetahuan tentang kanker payudara dan perilaku periksa payudara sendiri (sadari) disimpulkan bahwa karakteristik responden sebagian besar umur dewasa akhir (36-45) sebanyak 59 responden (59\%), sebagian besar pendidikan SMA sebanyak 45 responden (45\%), sebagian besar pekerjaan ibu rumah tangga sebanyak 82 responden (82\%), sebagian besar pengetahuan cukup sebanyak 37 responden $(37 \%)$, sebagian besar perilaku periksa payudara sendiri (SADARI) tidak dilakukan sebanyak 71 responden (71\%).

\section{SARAN}

Bidang Ilmu Keperawatan, hasil penelitian ini dapat menjadi suatu bahan masukan dan sumber informasi bagi ilmu 
Elda Dwi Ospah Sihite, Sofiana Nurchayati, dan Yesi Hasneli, Gambaran Tingkat Pengetahuan tentang Kanker Payudara dan Perilaku Periksa Payudara Sendiri (SADARI)

keperawatan dalam pengembangan ilmu keperawatan khususnya tentang pengetahuan kanker payudara dan perilaku periksa payudara sendiri (SADARI).

Bagi Puskesmas, hasil penelitian ini diharapkan menjadi pedoman dalam meningkatkan pengetahuan wanita usia subur tentang kanker payudara dan perilaku periksa payudara sendiri (SADARI).

Bagi Masyarakat, hasil penelitian ini diharapkan masyarakat terutama wanita usia subur senantiasa mencari tahu lebih dalam tentang pengetahuan tentang kanker payudara dan perilaku periksa payudara sendiri (SADARI).

Peneliti Selanjutnya, hasil penelitian ini diharapkan dapat menjadi data dan informasi bagi peneliti selanjutnya sehingga peneliti selanjutya dapat melanjutkan penelitian tentang melihat faktor-faktor berhubungan dengan tindakan deteksi dini kanker payudara melalui SADARI atau menghubungkan pengetahuan tentang kanker payudara dan perilaku SADARI.

\section{DAFTAR PUSTAKA}

Chentiana, D., Hayu, R., \& Rifa'i. (2017). Gambaran perilaku pemeriksaan payudara sendiri (sadari) pada wanita usia subur (wus) di dusun kanigoro desa puton kecamatan diwek kabupaten Jombang. Program Studi STIKES Pemkab Jombang. Diperoleh tanggal 29 April 2019 dari http://ejurnal. stikespemkabjombang.ac.id.

Desi, Priyantari, W., \& Lubis, U.P. (2017). Hubungan pengetahuan wanita usia subur tentang kanker payudara dengan sikap pemeriksaan payudara sendiri di Yogyakarta. Jurnal MIKKI, 5(1), 21-22.

Donnelly, T. (2015). Do socioeconomic factors influence breast cancer screening practices among Arab women in Qatar? BMJ Journal, 1-9. Diperoleh tanggal 29 April 2019 dari https://bmjopen.bmj. com.

Hanson. (2017). Knowledge and practice of breast self-sxamination among rural women in south west nigeria: implications for development of women empowerment programme. Africa Journal of Nursing and Midwifery, 19 (1), 144-156.

Internasional Agency for Researh on Cancer. (2018). Estimated cancer incidence, mortality and prevalence worldwide in 2018. Diperoleh tanggal 30 Januari 2019 dari http://gco.iarc.fr.

Kartika, D.O., Sutanto, D., \& Suciati, A. (2015). Gambaran sikap wanita usia subur tentang pemeriksaan payudara sendiri di desa pekauman kulon 
kecamatan dukuhtuti tahun 2015. E-Journal Politeknik Tegal Harapan Bersama, 104-106.

Kementerian Kesehatan Republik Indonesia. (2015). Pusat data dan informasi Kementrian Kesehatan RI. Diperoleh tanggal 26 Oktober 2018 dari www.depkes.go.id.

Notoatmodjo, S. (2012). Promosi kesehatan dan perilaku kesehatan. Jakarta: Rineka Cipta.

Nurhidayati, H. (2017). Gambaran keterampilan pemeriksaan payudara sendiri pada ibu-ibu pembinaan kesejahteraan keluarga (pkk). Program Studi Ilmu Keperawatan Fakultas Ilmu Kesehatan Universitas Muhammadiyah Surakarta. Diperoleh tanggal 26 April 2019 dari http://eprints.ums.ac.id.

Rasjidi, I. (2009). Deteksi dini \& pencegahan kanker pada wanita. Jakarta: CV Sagung Seto.

Rasjidi, I. (2010). 100 questions \& answer kanker pada wanita. Jakarta: Gramedia.

Saryono \& Roischa, D.P. (2009). Perawatan payudara dilengkapi dengan deteksi dini terhadap penyakit kanker payudara. Yogyakarta: Numet.

Suyatno \& Emir, T.P. (2014). Bedah onkologi diagnostik dan terapi. Jakarta: Sagung Seto.

Thaha, R \& Widajadnja, N. (2017). Hubungan tingkat pengetahuan tentang kanker payudara dan perilaku pemeriksaaan payudara sendiri (sadari) pada waktu wanita usia 20-45 tahun di desa sidera kecamatan sigi biromaru periode Juli tahun 2017. Jurnal Kesehatan Tadulako, 3 (2), 40-46.
Wawan, A \& Dewi, M. (2010). Teori \& pengukuran pengetahuan, sikap dan perilaku manusia. Yogyakarta: Nuha Medika

World Health Organization. (2018). Breat cancer: prevention and control. Diperoleh tanggal 30 Januari 2018 dari https://www.who.int.

Yayasan Kanker Payudara Indonesia (2017). Sadari (periksa payudara sendiri). Diperoleh tanggal 21 November 2018 dari http://pitapink-ykpi.or.id/sadariperiksa-payudara-sendiri. 